\title{
Formulation of Nanoparticles of Ethanol Extract of Garcinia mangostana L. Leaves as Antioxidant with Pectin as Cross-Linker and Chitosan Variation as Polymer
}

\author{
Diniatik, Anis Kusumawati, Agus Siswanto, Zaim Firdaus imtihan, Aji Wahyudi
}

\begin{abstract}
G. mangostana leaves contained xanthone substances, it could be used as antioxidants. Ethanolic extract of G. mangostana leaves were formulated into nanoparticles compound which were made available into nano size through ionic gelation method. G. mangostana leaves were extracted by using maceration method with $50 \%$ ethanol as solvent, then were continued with evaporation until thick extract were formed. The nanoparticle formulas were made by mixing G. mangostana extract in ethanol, a solution of chitosan in glacial acetic acid as a polymer, and pectin as a cross-linker solution. There were three formulas $(1,2,3)$ used, with the difference in pectin concentration which were $0.005 ; 0.01$; and 0.02 . Characterization of the three formulas include transmittance values were used spectrophotometric method and particle sizes by using particle size analysis (PSA). The results of this research showed that the transmittance of formulations 1, 2 and 3 were 95.9\%; 97.7\% and 97.3\%. The highest transmittance value was formula 3 , then were analysed its particle size and zeta potential were $2280 \mathrm{~nm}$ and $-20.6 \mathrm{mV}$.
\end{abstract}

Keywords: G. mangostana leaves, antioxidants, chitosan, pectin.

\section{INTRODUCTION}

The term "antioxidants" in Indonesia is now widely known and already familiar to public. The development of antioxidants by using natural antioxidants needs to be conducted. Natural antioxidants are relatively easy to get and safe. Antioxidants work by donating one of their electrons to the oxidant compounds so that the activity of those oxidant compounds can be hampered. ${ }^{[1]}$ Mangosteen (G. mangostana ) is a tropical plant which are widely spread and found in Southeast Asia, including Indonesia. Mangosteen is one of fruits that is liked by many people since its flavor and contents are beneficial for body. One of the main compounds in mangosteen is xanthone derivatives and this compound is

Revised Manuscript Received on August 22, 2019.

Diniatik, Faculty of Pharmacy, Universitas Muhammadiyah Purwokerto, Central of Java, Indonesia.Email: diniatik @ yahoo.com.au

Anis Kusumawati, Faculty of Pharmacy, Universitas Muhammadiyah Purwokerto, Central of Java, Indonesia.

Agus Siswanto, Faculty of Pharmacy, Universitas Muhammadiyah Purwokerto, Central of Java, Indonesia.

Zaim Firdaus Imtihan, Faculty of Pharmacy, Universitas Muhammadiyah Purwokerto, Central of Java, Indonesia.

Aji Wahyudi, Faculty of Pharmacy, Universitas Muhammadiyah Purwokerto, Central of Java, Indonesia. known to have activities namely antifungal, antimicrobial, antioxidant, and cytotoxic. ${ }^{[2]}$ This xanthone compound is found in the genus of Garcinia. ${ }^{[3]}$ Mangosteen peel extract has strong antioxidant activity, ${ }^{[4]}$ and mangosteen leaf extract has the potential as a natural antioxidant. ${ }^{[5]}$ The research on nanoparticles is currently developing rapidly because this research can be widely applied such as in environmental, electronic, optical, and biomedical fields. ${ }^{[6]}$ Nanoparticles are materials with particle size on the nanometer scale. ${ }^{[2]}$ The object of the nanoparticles is microscopic since it has very small size. Microscopic particles also have different quality and characteristic with macroscopic particles. The maximum mechanical characteristic occurs when the particle size is very small or nano-sized. ${ }^{[7]}$ The bigger particle size in micrometer scale up, the lesser mechanical characteristics will be, while particle size that is smaller than nanometer will result amorphous material. Many researches are conducted to find out the benefits of nanoparticles development. Nanoparticles used as drug delivery system show the result that particles or globul in nanometer scale have unique physical characteristics rather than the particles in bigger size particularly in improving the quality of drug compound delivery. ${ }^{[8]}$ The methods which can produce microparticles and chitosan nanoparticles from chitosan are emulsion cross-lingking, precipitation, spray drying, emulsion-droplet coalescence method, ionic gelation, reverse micellar method, and polyelectrolyte complex. ${ }^{[9]}$ The method that is mostly used is ionic gelation since this method is simple. Besides, this method can be controlled easily. The principle of the ionic gelation method is the occurence of ionic between positively charged amino groups in chitosan and polyanions which forms a three-dimensional intramolecular structure. ${ }^{[10]}$ Therefore, the researchers are interested to formulate mangosteen leaf extract in nanoparticle preparations by using ionic gelation method with the addition of pectin as cross-linker by varying the concentration of chitosan. It is expected that the benefits contained in mangosteen leaves can be more optimized considering that the particles in nano form have more advantages as drugs than macroparticles and microparticles. 


\section{METHODS}

\section{A. Instruments}

Analytical balance (Shimadzu BL 620S), Vial glass, micropipette with size 100-1000 micrometer, micropipette with size 10-100 micrometer, microtube, porcelain dish, pipette, pipette with volume $5 \mathrm{~mL}$, maceration jars, a set of glassware (measuring cylinder, beaker glass, test tubes, volumetric flask, funnel, and stirrer glass), Spectrophotometer UV-Vis (Shimadsu UV-1800 series), PSA (Particle Size Analyzer), a set of Sentrifuge instrument, filter paper, napkin, tissue, spatula, magnetic stirrer, aluminum foil, and a set of TLC (Thin Layer Chromatography) instrument.

\section{B. Materials}

The material from plant used in this research is $G$. mangostana leaves. Meanwhile, the chemical materials used in this research are 96\% ethanol (PT. Bratacho), aquades (PT.Bratacho), acetic acid (p.a) (Merck), Na-TPP (Natrium Tripolyphospate) (PT. Bratacho), and cellulose plate (Merck).

\section{Material Collection}

G. mangostana plant used is determined in Evirontment Laboratory of Faculty of Biology Universitas Jenderal Soedirman Purwokerto. G. mangostana leaves were taken from Banyumas regency, Central Java. Sampling is conducted in the same region with the same height. Drying process of the materials that have been washed cleanly are applied on the tray covered by black cloth in order to make those materials not exposed to direct sunlight. Then, they are spread out in the sun to dry. ${ }^{[11]}$

\section{Extraction of G. mangostana Leaves}

$200 \mathrm{~g}$ of G. mangostana leaves powder was mixed with $50 \%$ ethanol solvent until it is submerged then left it for 24 hours. The filtrate obtained is then collected and the rest of filtration is submerged again with the new solvent. Ethanol extract of G. mangostana leaves was concentrated by using waterbath tool with temperature $70^{\circ} \mathrm{C}$ until thick extract was obtained.

\section{E. Moisture content determination}

The empty crucible dish with its cover is weighed then its is heated into the oven with temperature $105^{\circ} \mathrm{C}$ for 30 minutes. Next, it is cooled into the desiccator for 15 minutes and it is weighed until the constant weight is obtained.

It is weighed precisely to be $\pm 1 \mathrm{gr}$ and it is put into the crucible that has been constanted. Crucible dish which contains extract is heated again with temperature $105^{\circ} \mathrm{C}$ for 1 hour. After being heated, it is cooled into the desiccator for 15 minutes then it is weighed. The drying process is continued in temperature $105^{\circ} \mathrm{C}$ until constant weight is obtained in which the difference of weighing done twice in a row is not more than $0.5 \mathrm{mg}$ for each gr of substance used. Loss on drying of the extract can be calculated with the formula as follows: moisture content $=\frac{a-b}{a} \times 100 \%$

Explanation:

$\mathrm{a}=$ Initial weight of extract

$\mathrm{b}=$ Final weight of extract

\section{F. Nanoparticle of Ethanol Extract of G. mangostana Leaves with Ionic Gelation Method}

Chitosan is made with concentration $0.01 \% \mathrm{~b} / \mathrm{v}$ that is dissolved into acetic acid $1 \%$ b/v. Pectin $0.05 \%-0.2 \%$ solution is made. Stock solution is produced by weighing $1 \mathrm{~g}$ G. mangostana extract dissolved into $100 \mathrm{~mL}$ ethanol $50 \% .1$ $\mathrm{mL}$ extract stock solution is added into pectin $0.05 \%-0.2 \%$ solution by dropping it and stirring it using magnetic stirrer. Then, the mixture of extract and pectin (concentration variation $0.05-0.2 \% \mathrm{~b} / \mathrm{v}$ ) is added into chitosan solution drop by drop in room temperature under the spin of magnetic stirrer with the speed $1500 \mathrm{rpm}$ during 2 hours until nanoparticle suspension is formed. Nanoparticle formula of mangosteen leaf ethanol extract can be seen on the Table 1. The formulation of nanoparticle extract is conducted with comparisons between chitosan, pectin and extract respectively which are 5:1:1.

Table 1. Nanoparticle Formulation

\begin{tabular}{lccc}
\hline Samples & F1 & F2 & F3 \\
\hline $\begin{array}{c}\text { ethanol extract of } G . \\
\text { mangostana levaes }(\mathrm{mg} / \mathrm{ml})\end{array}$ & 10 & 10 & 10 \\
\hline $\begin{array}{c}\text { Chitosan content (\% b/v) in } \\
5 \mathrm{ml} \text { acetic acid solution 1\% }\end{array}$ & 0.01 & 0.01 & 0.01 \\
\hline $\begin{array}{c}\text { Pectin content (\% b/v) in 1 } \\
\text { ml water solution }\end{array}$ & 0.05 & 0.1 & 0.2 \\
\hline
\end{tabular}

\section{Transmittance}

Nanoparticle of G. mangostana leaves extract was good to have a cleear visual eishting with a transmittance of more than $90 \%$ so that the formula could be said to form a nanoparticle.

Transmittance was conducted by observing the samples spectrophotometrically through reading the trasmittance on $650 \mathrm{~nm}$ wavelength using aquades as the standard.

\section{G. Free Radicals Scavenging Activity By Using Dpph (2.2-Diphenyl-1-Pikrilhidrazil) Method}

\section{Determination of the Maximum Wavelength of DPPH}

Determination of maximum wavelength of DPPH 0.004 $\%$ solution for antioxidant activity test on nanoparticle formula of mangosteen leaf ethanol extract is conducted as follows: $5 \mathrm{ml}$ DPPH $0.004 \%$ solution, its absorbance is observed on the wavelength range $400-700 \mathrm{~nm}$ by using methanol blank.

\section{Determination of Operating Time}

Measurement is done by taking one of the concentration solutions from methanol extract, $4 \mathrm{ml}$ concentration solution taken is added with $1 \mathrm{ml} \mathrm{DPPH}$, its absorbance is read on the wavelength $515 \mathrm{~nm}$ from some minutes which are: 5, 10, 20, $30,40,50,60$. The result of operating time determination is where the absorbance has 
reached constant value and there is no decline anymore.

\section{Measurement of Free Radicals ScavengingActivity}

The measurement is started by making the series of concentration for extract namely $18,16,15$, and $10 \mu \mathrm{g} / \mathrm{ml}$. Then, take $4 \mathrm{ml}$ from each comparison and added with $1 \mathrm{ml}$ DPPH $0.004 \%$ solution. After that, they are incubated in the closed tubes in order to make them protected from the light in room temperature during operating time. From the result of incubation, its absorbance is measured by using spectrophotometer UV-Vis on its optimal wavelength. The absorbance value obtained is then used to result the percentage of radicals interception and to get the regression equation:

$$
\mathbf{Y}=\mathbf{a}+\mathbf{b x} \text {. }
$$

$\mathrm{IC}_{50}$ value is calculated by using that regression equation formula. The lowest $\mathrm{IC}_{50}$ value shows the highest antioxidant activity. Inhibition of nanoparticles toward DPPH can be calculated with the equation below:

$$
\% \text { inhibition }=\frac{(\text { A control }- \text { A sample })}{\text { A control }} \times 100 \%
$$

Explanation:

$\%$ inhibition $=$ percentage of antioxidant inhibition

A control $=$ absorbance of DPPH

A sample = absorbance of testing solution

Then, the results obtained are put into regression equation with the concentration of sample or extract $(\mu \mathrm{g} / \mathrm{ml})$ as the basis ( $\mathrm{X}$ axis) and the percentage $(\%)$ of antioxidant inhibition as the ordinate ( $\mathrm{Y}$ axis). $\mathrm{IC}_{50}$ value from the calculation when the percentage $(\%)$ of inhibition is $50 \%$ with $\mathrm{Y}=\mathrm{Ax}+\mathrm{b}^{[7]}$

\section{H. Analysis}

Quantitative analytical technique applied in this research is PSA (Particle Size Analyzer). PSA instrument is used for finding out nanoparticle size resulted and Zeta Sizer Nano Series malvem for finding out potential Zeta value.

\section{RESULTS}

From the determination result, there is a certainty that the plant used in this research comes from Clusiaceae family with Garcinia genus and has species name which is Garcinia mangostana L. The powder of G. mangostana (580 g) were macerated by using maceration method with $50 \%$ ethanol solvent $(5.8 \mathrm{~L})$, then were re-macerated by using $3.6 \mathrm{~L}$ of the same solvent. Both filtrates were evaporated to obtain thick extract with weight $157.80 \mathrm{~g}$ (dark brown color, typical smell). Thick extract of $G$. mangostana leaves were showed in the fig.1.

Table 1. Yield Percentage of G. mangostana Leaves Extract

\begin{tabular}{cccc}
\hline $\begin{array}{c}\text { G. mangostana } \\
\text { Leaves }(\mathbf{g})\end{array}$ & Powder $(\mathbf{g})$ & $\begin{array}{c}\text { Extract Weight } \\
(\mathbf{g})\end{array}$ & Yield (\%) \\
\hline 2500 & 580 & 157.80 & 27.20 \\
\hline
\end{tabular}

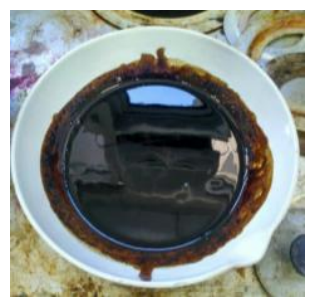

\section{Fig. 1. G. mangostana Leaves Thick Extract}

Moisture content of exteract were obtained by using gravimation methods. Determination of moisture content were used to find out water content and solvent which still remains inside the extract. The thick extracts were dried in temperature $105^{\circ} \mathrm{C}$ until obtained constant weight in which the difference of weighing done twice in a row is not more than $0.005 \mathrm{~g}$ for each $\mathrm{g}$ of substance used. ${ }^{[12]}$ Based on the test that has been conducted, the percentage of moisture content was $23.194 \%$. This percentage showed that the extract includes thick extract since the percentage of water content and solvent in G. mangostana leaves extract reaches $5 \%-30 \% .^{[13]}$

The process of producing the formulation of nanoparticle preparations from ethanol extract of $G$. mangostana leaves applies ionic gelation method. The formula can be seen in Table 1. Ethanol extract of $G$. mangostana leaves were formed by using maceration method with concentration $50 \%$ of solvent ethanol, then evaporated to obtain thick extract. Based on Diniatik's research (2014), $1-2 \mathrm{mg} / \mathrm{ml}$ of $50 \%$ ethanol extract of G. mangostana leaves can give better preservative effect than soluble preservative material.

The selection of chitosan polymer and pectin as formulas in producing nanoparticle preparations from G. mangostana leaves extract is because both formulas have advantages that are related to each other. The use of chitosan in nanoparticle production is because chitosan is natural biopolymer which has special characteristics such as mucoadhesive, biocompatible, biodegradable, non toxic and low imonogenicity level. Besides, chitosan is biomaterial that is very promising as carrier in drug delivery system. In the form of nanoparticle, chitosan is considered as carrier that is very promising in increasing bioavailability and biomolecules since chitosan has better abilities in diffusion and penetration into mucus layer. The mechanism of nanoparticle formation based on electrostatic interaction between amine group from chitosan and negative group from polyanion forms intermolecule and/or 3-dimensional intramolecule network structures. Cross-linker used is pectin since it is non toxic and has multivalent. The formula made forms a suspension solution that has orange color (Fig. 2) and then it is characterized a transmittance measurement (\%T), PSA (Particle Size Analizer) in order to know the particle size that is formed, Potential Zeta, and TLC test for finding out the similarities of the components contained in G. mangostana leaves extract in nano size or in the form of nanoparticle preparations.

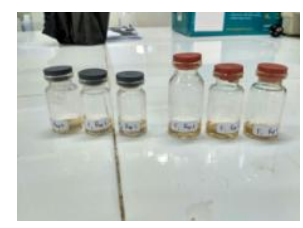

Fig. 2. Nanoparticle of ethanolic extract of G. mangostana leaves (a) F1 with 0.05 pectin (b) F2 with 0.1 pectin (c) F3 with 0.2 pectin. and Engin है IJRTE 
From the three samples, the transmittance result in sample F1 has good clarity since it approaches $100 \%$. According to ${ }^{[2]}$, the clarity of water and the transmittance result which approaches aquades signify that the droplets formed are getting smaller so that they are estimated to have droplet size $<1 \mu \mathrm{m}$. The result of the transmittance percentage $(\%)$ of nanoparticle formula of mangosteen leaves can be seen in the Table 2.

Table 2. Tranmittance (\% $\mathrm{T}$ ) of Nanoparticle of ethanolic extract of $G$. mangostana leaves

\begin{tabular}{ccc}
\hline Formula & Transmittance ( $\square$ ) & Average (\%) \\
\hline F1 & 96.523 & 95.958 \\
& 95.679 & \\
& 95.679 & \\
F2 & 96.767 & 97.173 \\
& 98.067 & \\
F3 & 96.686 & 97.350 \\
& 97.266 & \\
& 97.771 & \\
\hline
\end{tabular}

Based on the transmittance, it is found that F3 was the highest. Observation of particle size by using PSA (Particle Size Analizer) from F3 obtained particle size of $2280 \mathrm{~nm}$. Thus it is still micron-sized. F3 has a zeta potential value of $-20.6 \mathrm{mV}$ which is still less than $-25 \mathrm{mV}$ so that it is still possible to form aggregates. Potential Zeta of F3 resulted nanoparticles which have less stable potential Zeta value since they are considered to have potential value which is lesser than $-30 \mathrm{mV}$ and more than $+30 \mathrm{mV} .^{[15]}$ From the results above, it is found that the higher pectin concentration $(0.2 \%)$, the smaller diameter of particle size will be. Further, the smaller particle size of a preparation, the more stable that preparation in accordance with its function will be. The function of producing nanoparticle preparations is to stable the preparations themselves. Besides determining particle size, the measurement of potential Zeta value is also very important in producing nanoparticles. Potential Zeta value is related to the stability of nanoparticle suspension which shows nanoparticle electrostatic interaction among particles. Potential Zeta also reflects potential contents from particles that are influenced by the composition from particles and medium where nanoparticles are dispersed. Therefore, potential Zeta has important roles in the stability of a solution. Potential Zeta is also related to surface physical stability which prevents the occurence of particle aggregation. Reducing potential Zeta will cause aggregation and sedimentation in line with the style of Van Der Waals in particle interaction. ${ }^{[16][17]}$ The high value of deflocculation happens if the value is between $+60 \mathrm{mV}$ to $100 \mathrm{mV}$ and -60 $\mathrm{mV}$ to $-100 \mathrm{mV}$ which shows the levels of suspension deflocculation. Flocculation always occurs if potential Zeta value approaches 0 , namely between $+10 \mathrm{mV}$ to $-10 \mathrm{mV} .^{[18]}$

Chitosan is natural biopolymer caused by the existence of reactive amino group and hydroxil functional group that can bind with unpaired atoms or free radicals. Three formulas of nanoparticle preparations of mangosteen leaves consitst the same concentration of chitosan. Chitosan is one of immobilization matrices that is mostly promising since it has ability to form membrane, good adhesive characteristic, non toxic, and have mechanical strength, high hydrophilicity, and stability improvement. [20][21] Furthermore, nanoparticle of ethanolic extract of $G$. mangostana leaves possessed antioxidant activity because of its activity and encouraged with chitosan as one of materials to producting nanoparticle.

The measurement of absorbance of DPPH $0,004 \%$ solution on 400-800 $\mathrm{nm}$ wavelength, the result shows that the maximum wavelength of DPPH solution is $516 \mathrm{~nm}$ with absorbance value 0.4162 . This indicates that the absorbance measurement on antioxidant activity test is conducted on the maximum $\lambda$ namely $516 \mathrm{~nm}$. Operating time is meant to get optimal time which is needed by the extract to give antioxidant effect to DPPH free radicals. The result of operating time determination is 15 minutes with absorbance value 0.338 in which in this absorbance, constant value has been reached and there is no decrease or increase anymore so that it is the optimal time needed by DPPH to react with the tested formula.

Table 3. IC $_{50}$ Value of Extract and Quercetin

Inhibition concentration $\mathrm{IC}_{50}(\mu \mathrm{g} / \mathrm{ml})$

\begin{tabular}{cccc}
\hline & replication 1 & replication 2 & replication 3 \\
\hline Extract & 0.85 & 0.80 & 0.79 \\
\hline Quercetin & 0.13 & 0.13 & 0.13 \\
\hline
\end{tabular}

Ethanolic extract of $G$. mangostana leaves possessed antioxidant activity five times less than quercetin (Table 3). It can be seen from $\mathrm{IC}_{50}$ value in extract which has $\mathrm{IC}_{50}$ value namely $0.81 \mu \mathrm{g} / \mathrm{ml}$. $\mathrm{IC}_{50}$ is concentration of sample solution that is required to obstruct $50 \% \mathrm{DPPH}$ free radicals. The higher percentage $(\%)$ of scevenging value, the lower $\mathrm{IC}_{50}$ value will be. The higher $\mathrm{IC}_{50}$ value, the lower antioxidant power will be meaning that the more concentration is needed by a sample to give $50 \%$ obstruction. ${ }^{[19]}$ Quercetin is used as comparison because it is a strong antioxidant which has free radical scavenging activity although the concentration is low. Specifically, a compound is considered as very strong antioxidant if its $\mathrm{IC}_{50}$ value is less than $50 \mu \mathrm{g} / \mathrm{ml}$, strong for $\mathrm{IC}_{5 \mathrm{C}}$ value between 50 to $100 \mu \mathrm{g} / \mathrm{ml}$, medium for $\mathrm{IC}_{5 \mathrm{C}}$ value between 100 to 150 $\mu \mathrm{g} / \mathrm{ml}$, and weak for $\mathrm{IC}_{5 \mathrm{C}}$ value between 151 to $200 \mu \mathrm{g} / \mathrm{ml}^{[7]}$

Working mechanism of antoxidant is scavenging free radicals by giving one or more electrons to free radicals so that they become normal molecular form again. Secondary metabolite from G. mangostana leaves extract which can be found and is responsible to have ability as antioxidant is xanthone flavanoid. Xanthone flavanoid derivatives that can be isolated from leaf are 1,5,8-trihydroxy-3-methoxy-2-(3-methylbut-2-enyl) xanthone

1,6-dihydroxy-3-methoxy-2-(3-methyl-2-buthenyl) xanthone. ${ }^{[2]}$

and 

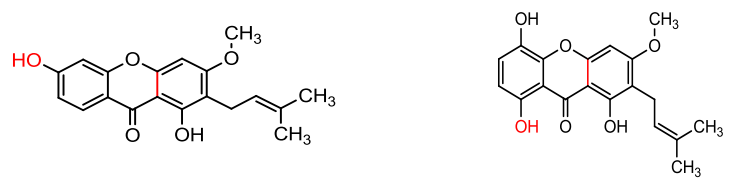

1,6-Dihydroxy-2-(2hydroxy-3-methylbut-3enyl)-

3,7-dimethoxy-8-(3methylbut-2-enyl)-xanthone 1,5,8-Trihydroxy-3methoxy-2-(3-methylbut-2enyl) xanthone

Fig.4 Xanthone Structure Contained in G. mangostana leaves ${ }^{[22]}$

\section{CONCLUSIONS}

Based on the research that has been conducted, the conclusions that can be drawn are as follows:

Nanoparticles of ethanol extract of $G$. mangostana leaves in formulation F3 were better than F1 and F2 in which concentration of chitosan in glacial acetic acid is $0.01 \%$ and concentration of pectin is $0.2 \%$, with transmittance 97.35 , particle size $2280 \mathrm{~nm}$ and zeta potential $-20,6 \mathrm{mV}$.

Antioxidant activity of ethanol extract from $G$. mangostana leaves with DPPH free radical scavenging method showed five time less than quercetin, but its $\mathrm{IC}_{50}$ value $0.81 \mu \mathrm{g} / \mathrm{ml}$ (very strong antioxidant because its $\mathrm{IC}_{5 \mathrm{C}}$ value was less than $50 \mu \mathrm{g} / \mathrm{ml})$. It can be conclude that formula 3 (F3) has strong antioxidant activity, respectively.

\section{ACKNOWLEDGEMENT}

We would like to thank Directorate General of Higher Education, Ministry of Research Technology and Higher Education Republic of Indonesia for the research funding.

\section{REFERENCES}

1. Winarsi, H. 2007. Antioksidan Alami \& Radikal Bebas. Kanisius. Yogyakarta: 11-20, 79-82, 147-161.

2. Rismana, E., Kusumaningrum, S., Bunga, O., Nizar, and Marhamah. 2014. Pengujian Aktivitas Antiacne Nanopartikel Kitosan - Ekstrak Kulit Buah Manggis (Garcinia mangostana). Media Litbangkes, 24(1): 19-27.

3. Izzati, N.N, Diniatik, and Rahayu S.R. 2012. Aktivitas Antioksidan Ekstrak Perasan Daun Manggis (Garcinia mangostana L.) Berdasarkan Metode DPPH (2,2 Diphenyl-1-phycryl hydrazil). Jurnal Fakultas Farmasi, Universitas Muhammadiyah Purwokerto, 9(3): 111-120.

4. Mardawati, Filiantiy F., Marta, H. 2010. Jurnal Kajian Aktivitas Antioksidan Ekstrak Kulit manggis (Garcinia mangostana L.) Dalam Rangka Pemanfaatan Limbah Kulit Manggis Di Kecamatan Puspahiang Kabupaten Tasikmalaya. Bandung: Universitas Padjajaran.

5. Diniatik, Suparman, Anggraeni D., Amar I. 2016. Uji Antioksidan Ekstrak Etanol Daun Dan Kulit Batang Manggis (Garcinia mangostana L.). Pharmaciana, 6(1): 21-30.

6. Tatang, W., Sugiyana D., and Helmy Q. 2011. Sistesis Nanopartikel Perak dan Uji Aktivitasnya terhadap Bakteri E.Coli dan S.aureus. Bandung: Balai Besar Tekstil.

7. Zuhra, C.F., Tarigan, J.B., and Sihotang, H. 2008. Aktivitas Antioksidan Senyawa Flavonoid dari Daun Katuk (Sauropus androgunus (L) Merr.) Jurnal Biologi Sumatra, 3(1): 10-13.

8. Martien, R., Adhyatmika, Iramie D.K.I., Farida, V., and Dian P.S. 2012. Perkembangan Teknologi Nanopartikel sebagai Sistem Penghantaran Obat. Majalah Farmaseutik, 8(1): 133-144.

9. Kurniasari, D. 2016. Pembuatan Dan Karakterisasi Nanopartikel Ekstrak Etanol Temu Kunci (Boesenbergia pandurata) Pada Berbagai Variasi Komposisi Kitosan. Skripsi. Yogyakarta. Fakultas Matematika dan Ilmu Pengetahuan Alam Universitas Negeri Yogyakarta.

10. Agnihotri SA, Nadagounda N, Mallikarjuna, Tejraj M, Aminabhavi. 2004. Recent advances on chitosan based micro and nanoparticles in drug delivery. J.Control. Release, 100:5-28.

11. Fatchurozak, Suranto dan Sugiyarto. 2013. Pengaruh Ketinggian Tempat Terhadap Kandungan Vitamin C dan Zat Antioksidan pada Buah Carica pubescens di Dataran Tinggi Dieng. Surakarta. Jurnal Pasca UNS 1(1): 24-31.

12. Indrasuari, A.A.A; N.P.A.D, Wijayanti; I G.N.A, Dewantara,. 2014 Standarisasi Mutu Simplisia Kulit Buah Manggis (Garcinia mangostana L.). Jurnal Farmasi Udayana, ISSN 2301-7716, 99-101.
13. Saputra, G., Purwanti, N.U., and Taurina, W. 2016. Karakterisasi Nanoenkapsulasi Kitosan-Ekstrak Etanol 70\% Daun Sirih (Piper Betle Linn) Dengan Metode Gelasi Ionik. Naskah Publikasi. Pontianak: Studi Farmasi, Fakultas Kedokteran, Universitas Tanjungpura.

14. [DepKes RI] Departemen Kesehatan Republik Indonesia. 2000. Parameter Standar Umum Ekstrak Tumbuhan Obat. Jakarta: Departemen Kesehatan Republik Indonesia. Page 3-30.

15. Murdock, R.C., Braydich-Stole, L., Schrand, A.M., Schlager, J.J., Hussain, S.M. 2008. Characterization of Nanoparticle Dispersion in Solution Prior to In Vitro Exposure using Dynamic Light Scattering Tehnique. Toxicol, Sci, 101: 239-253.

16. Jahanshahi, M. and Babaei, Z. 2008. Protein Nanopartikel: A Unique system as Drug Delivery Vehicle. J. Biotechnology, 7(25): 4926-4934.

17. NanoComposix. 2012. Nanocomposix's Guide To Dynamic Light Scattering Measurement And Analysis. San Diego : NanoComposix. 1(3).

18. Dinger, D. D. 2010. Practical Pointers for Ceramist vol 2. C B Dinger halaman 68

19. Asmarani, C. F. Iis Wahyuningsih. 2015. Pengaruh variasi Konsentrasi Tween 80 dan Sorbitol terhadap Aktivitas Antioksidan Minyak Zaitun (Oleum olivae) dalam Formulasi Nanoemulsi. Farmasains. Yogyakarta. 2(5)

20. Nakorn, P.N. 2008. Chitin Nanowhisker and Chitosan Nanoparticles in Protein Immobilization for Biosensor Applications. J. of Metals, Materials and Minerals. 18(2): 73-77.

21. Erdawati, 2008. Kapasitas adsorpsi kitosan dan nanomagnetik kitosan terhadap ion Ni (II). Prosiding, Seminar Nasional Sains dan Teknologi II, Universitas Lampung. (3): 248-256.

22. Obolskiy D, Pischel I, Siriwatanametanon N, Heinrich M. Garcinia mangostana L.: A phytochemical and pharmacological review. Phytotherapy Research 2009, 23(8): 1047-1065.r

\section{AUTHORS PROFILE}

Diniatik, Faculty of Pharmacy, Universitas Muhammadiyah Purwokerto, Central of Java, Indonesia.Email: diniatik@yahoo.com.au

Anis Kusumawati, Faculty of Pharmacy, Universitas Muhammadiyah Purwokerto, Central of Java, Indonesia.

Agus Siswanto, Faculty of Pharmacy, Universitas Muhammadiyah Purwokerto, Central of Java, Indonesia.

Zaim Firdaus Imtihan, Faculty of Pharmacy, Universitas Muhammadiyah Purwokerto, Central of Java, Indonesia.

Aji Wahyudi, Faculty of Pharmacy, Universitas Muhammadiyah Purwokerto, Central of Java, Indonesia. 